\title{
The Appearance and Subordination of Women: An examination of the increased emergence of symbolic female imagery and the subordination of women during the French Revolution
}

Lily Climenhaga

\begin{abstract}
The author explores historiography of Enlightenment in context of cultural history, drawing from various sources.
\end{abstract}

The Enlightenment has an extremely broad and varied historiography. Hundreds of books and articles have been dedicated to the intellectual and political history of the Enlightenment and many more biographies have been dedicated to Enlightenment intellectuals. The history of the Enlightenment also represents a neglected area of history for many minority groups.

Traditionally Enlightenment history has been dedicated to a particular group of men viewed as intellectuals such as Voltaire, Isaac Newton and Jean-Jacques Rousseau. One of the major groups excluded from the intellectual history of the Enlightenment was women.

Women within Western historiography prior to the 1960s generally played a minor role within history. The marginalization of women had to do with Whig history, a history written by white, middle-class, Protestant men for white, middle-class, Protestant men. Women did not write the major histories or historical documents typically studied by historians and have been denied an active role within history. However, within the past two decades the idea women did not write history has been challenged. During the Enlightenment period in particular an increasing number of women began publishing manuscripts, both fiction and non-fiction, across Europe.

Women played a marginal role within most histories written until recently with the emergence of feminism. Intellectual history was essentially a great man's history, which typically served to marginalize and exclude women. Women were effectively defined as the "Other" within the intellectual history. Using the Saidian logic of the other, women are seen as point against which men were measured. Women were fundamentally different from men in their physiology, mental capacities, social and gender roles. ${ }^{1}$ Throughout this paper I will examine the historiography of women within the Enlightenment. An examination of the historiography of women in the Enlightenment poses a significant challenge, because there is a large gap in the historiography.

During the Enlightenment period both men and women wrote about the role of men and women and their natural place within society. Women's status as inferior to men during this period became institutionalized through the work of many intellectuals who labeled women as lacking the intellectual capacities men held. These labels were naturalized and have acted as proof of male superiority within history effectively labeling women as resistant to the progression of history and "Other", fundamentally different, to men. ${ }^{2}$ One must look no farther then the writing of Jean-Jacques Rousseau whose writings discussed the role of women within society or, to be

\footnotetext{
${ }^{1}$ Jenny Mander, "No Women is an Island: The Female Figure in French Enlightenment Anthropology," in Women, Gender, and Enlightenment ed. Sarah Knott and Barbara Taylor (New York: Palgrave Macmillan), 99.

${ }^{2}$ Carla Hesse, The Other Enlightenment: How French Women Became Modern (Princeton: Princeton University Press, 2003), 37-40.
} 
more precise, their role within the home. ${ }^{3}$ Another example is Francois Poulain de La Barre a French writer, feminist philosopher and Cartesian who put forth a new educational model for women in the 1700s. Although both La Barre and Rousseau are long dead they continue to play an important role within history writing. Many historians continue to write history within the biases of these theorists. An example of these biases is Rousseau and his discourse on women, which excluded women from the public sphere. As discussed later, historian Dena Goodman expressed her aversion to the Rousseauian bias that has contributed to the marginalization of Enlightenment women within many modern histories.

Following the Enlightenment, few major histories were written about female intellectuals. The exception was histories about salon culture where female salonnaires took on a minor role as hostesses. Women's history disappeared until the late 1980s and 1990s when an advent of new histories from authors such as Joan Scott, Joan Landes, Suzanne Desan and many others. The gap within the historiography from essentially the Enlightenment until the 1990s was caused by a male-centric focus within history for hundreds of years. Only since the 1960s with the emergence of second wave feminism, other social movements and the advent of cultural and social history have marginalized groups become historically relevant topics for historians. Within the historiography of Enlightenment women one must examine the relation of women to the public sphere. This study illustrates how historians are negotiating women's role within history as active members of Enlightenment intellectual society.

Jürgen Habermas' concept of the public sphere has plagued historians since the publication of The Structural Transformation of the Public Sphere: An Inquiry into a Category of Bourgeois Society. Habermas' public sphere represents an imagined space I have equated with the imaged space of the West. The public sphere is a privileged space only active individuals can inhabit. This space exists in opposition to the private sphere, another imagined space equivalent to Said's Orient. Similar to Said's concept of the Orient and the Occident, the private and public spheres exist in relation and as reflections of each other. Both the private and public spheres represent a space of exclusion. Only certain members of society can be part of the public sphere and those who do not belong to the public sphere are restricted to the private sphere. Membership into these spheres and one's place within the sphere is prescribed based on social and gender norms. ${ }^{4}$

Women were inherently excluded from the early public sphere because of gender ${ }^{5}$ and their rightful place within the household. Habermas defines the public sphere as, "the state [...] that had developed [...] into an entity having an objective existence over against the person of the ruler," while the private sphere is "the exclusion from the sphere of the state apparatus."

\footnotetext{
${ }^{3}$ Jean-Jacques Rousseau, "Emile (1762)," in Women, the Family, and Freedom: The Debate in Documents, vol 1: 1750-1889, ed by Susan Groag Bell and Karen M. Offen (Stanford: Stanford University Press, 1983), 43-49. http://chnm.gmu.edu/revolution/searchfr.php? function=find \&x=0\&y=0\&keyword=Emile\#.

${ }^{3}$ Edward Said, Orientalism (New York: Pantheon, 1978)

${ }^{4}$ Said, Orientalism, 5.

${ }^{5} \mathrm{I}$ am cautious not to use the term sex, because sex is the biological category differentiating between the physical differences of male and female bodies, whereas gender is a imagined binary, although one can easily argue sex is imagined as well, that imbues and naturalizes men and women with different roles and traits. Women were excluded from the public sphere and the other categories discussed throughout this paper based on gender and potential deviation from gender norms not because of their biological sex, although the two are connected.

${ }^{6}$ Jürgen Habermas, The Structural Transformation of the Public Sphere: An Inquiry into a Category of the Bourgeois Society, translated by Thomas Burger assisted by Frederick Lawrence (Cambridge: MIT Press, 1991 ), 11.
} 
terminology used by Habermas illustrates the nature of the individuals within each sphere. The private sphere is literally a space of exclusion because membership into the private sphere inherently means rejection from the public sphere. Men were active and therefore belonged within the public sphere because they were considered "by nature" active, while women were inherently and inseparably connected to the domestic, private, sphere because of their roles as wives and mothers. Joan Landes in Women and the Public Sphere in the Age of the French Revolution argued with the emergence of the Habermasian public sphere a dramatic gender differentiation occurred. The emerging binary ended, according to Landes, in the creation of the modern state, which because of its political nature was "essentially [...] masculine."7

Male authors such as Rousseau were influential in shaping Enlightenment historiography. Works by Charles de Secondat, the baron de Montesquieu; Samuel Richardson and many others were important to women's history, not because they provided an accurate image of women or an accurate history of female behaviour, but because their texts provide insight into how women were viewed in the public and private spheres. Rousseau in both his novels Julie and Emile provided an image of women belonging solely to the private sphere as mothers and wives. ${ }^{8}$ Rousseau's Emile describes Emile's wife Sophie as the ideal woman, quiet and respectful to her husband. Rousseau stated, "woman is made to please and be subjugated to man." These writings overtly exclude and remove women from the public sphere and place them within the private sphere. For many years historians continued excluding women from the public sphere until it was rejected during the nineties by feminist and cultural historians such as Dena Goodman.

Before the late 1980s women were represented within a male-centric ideology and placed within the home. Said in Orientalism describes the Oriental as "made Oriental." "This reasoning can be applied to women within the Enlightenment as well. According to historian Joan W. Scott women acted as the "Other" for men to normalize the social and political differentiation between men and women. ${ }^{11}$

Histories written prior to the late 1980s naturalized the exclusion of women from the public sphere by failing to mention women as contributors or participants within history. These histories were challenged when cultural histories and feminist histories started to be published. Historians currently face the challenge of attempting to place women as active participants within the public sphere and answer the question, "to what extent women can be granted an active role within society?" The significance of salon society to both men and women has been extensively studied within the past two decades. In comparison to the academies, which have been traditionally gendered male, the salons are seen as a space of male and female interaction. Salons, according to Steven Kale, allowed interaction between men and women, but did not allow the mixing of social classes as the academies did. Membership in academies varied from noble roots, Robert Boyle, to those from humble origins, Isaac Newton. ${ }^{12}$ However, the gendered space of the

\footnotetext{
${ }^{7}$ Joan B. Landes, Women and the Public Sphere in the Age of the French Revolution (Ithaca, NY: Cornell University Press, 1988), 6-7.

${ }^{8}$ Lynn Hunt, Inventing Human Rights: A History (New York: W. W. Norton and Company, 2007), 41-42.

9 "Emile (1762)"

${ }^{10}$ Said, Orientalism, 6.

${ }^{11}$ Joan Wallach Scott, Only Paradoxes to Offer: French Feminists and the Rights of Man (Cambridge: Harvard University Press, 1996), 3.

${ }_{12}$ Antoine Lilti, "Sociability and Mondanité: Men of Letters in the Parisian Salons of the Eighteenth Century," transl. Jeremy Caradonna (n.d), 1-29.
} 
academies has recently come into question as certain academies allowed female membership for women who won academic prize competitions.

Alyssa Goldstein Sepinwall examined the inclusion of women into academies during the time of Maximilien Robespierre. Her examination reveals some women were accepted into academies with the support of male members such as Robespierre, whose later actions during the French Revolution proved disastrous for women's rights. ${ }^{13}$ A Rousseauian bias within history becomes evident when presented with this evidence (Robespierre as an early supporter of female intellectuals). Historians have ignored information about Robespierre prior to his ideological shift to Rousseauianism ${ }^{14}$. A conclusion cannot be inherently drawn that prior to the French Revolution women were viewed exclusively through a Rousseauian lens as many historians have. To project these views onto all intellectuals illustrates the modern bias and assumptions about how individuals during the Enlightenment viewed their society. As illustrated below, within Enlightenment historiography there is significant disagreement between historians what role women played within Enlightenment society.

Dena Goodman in The Republic of Letters: A Cultural History of the French Enlightenment wrote in stark opposition of the Rousseauian historians, such as Daniel Mornet, fervently stating the importance of women within Enlightenment France. Goodman's women are at the center of Salon society as not just as the keepers of polite conversation, but as a vital part of the intellectual culture of salon society. ${ }^{15}$ Goodman attempted to increase the importance of women within the early French Enlightenment by making them the governors of the intellectual work within the salon by enforcing the rules of polite and intellectual conversation. ${ }^{16}$ However, Goodman inflates the role of women within the public sphere and intellectual history. One must look no further then the work of Antoine Lilti to find opposition to Goodman's work. Lilti does not deny the presence of women within the salon as governors of polite conversation, but he does bring into question the role of salon society in intellectual life. Although women held the role of governors the salons were not intellectual spaces as Goodman claimed, but rather social spaces. ${ }^{17}$ This shift indicated by Lilti illustrates a shift away from the feminist tradition of writing women into history.

Goodman's book represents a selection of work within the historiography of women in the Enlightenment that can be described as an "over-correction". Many female historians attempted to correct the long-standing tradition of male dominated histories marginalizing women by rewriting the role of women in history. Goodman placed women at the center of salon society, an

\footnotetext{
${ }^{13}$ Alyssa Goldstein Sepinwall, "Robespierre, Old Regime Feminist? Gender, the Late Eighteenth Century, and the French Revolution Revisited," in The Journal of Modern History 82:1 (March 2010), 1-29. http://ehis.ebscohost.com.login.ezproxy.library.ualberta.ca/eds/pdfviewer/pdfviewer?sid=fd844e71-6a80-4237bd33-b69506949470\%40sessionmgr115\&vid=4\&hid=117.

${ }^{14}$ What I am defining as Rousseauiansim is the ideology in which women are excluded from the public sphere on the grounds their natural place within society was in the house. Although Rousseau was by no means the first philosopher to have this theory, because of his status within the philosophical canon and the influence his work had during the French Revolution within this essay the term Rousseauian is employed to describe the exclusionary discourse surrounding women during the Enlightenment and still present within the historiography.

${ }^{15}$ Dena Goodman, The Republic of Letters: A Cultural History of the French Enlightenment (New York: Cornell University, 1994), 6.

16 ibid, 91 .

${ }^{17}$ Lilti, "Sociability and Mondanité," 3.
} 
intellectual space designated for both male and female intellectuals. However, further examination in the field of salon society by historians such as Lilti has placed salons within the social sphere as an important source of connections. The importance of salons within intellectual culture has not been reduced, but instead transposed the importance to a social instead of intellectual medium. Women remain as an important aspect of intellectual life and Lilti identifies women as important patrons and supporters of members of their salons. ${ }^{18}$ Thus histories from academics like Lilti do not insert women into intellectual history, but instead to uncover the role women played in intellectual history.

Within much of Enlightenment historiography the female presence in salon society was the only place women appeared within intellectual society. Modern neoconservative historians such as Gertrude Himmelfarb continue to exclude women. Himmelfarb's book The Roads to Modernity: the British, French and American Enlightenments examined the works and lives of philosophes, philosophers and Enlightenment thinkers such as David Hume, Thomas Paine and Adam Smith. Within her book Himmelfarb seldom refers to women. Those mentioned, even influential female activists such as Mary Wollstonecraft, are dismissed as acting under the influence of men. ${ }^{19}$

Himmelfarb, Ernst Cassirer, Paul Hazard and Jonathan Israel are just a few historians whom, in their examinations of Enlightenment history, have excluded women. Israel includes a short section on women in his Radical Enlightenment only focusing on salonnaires, upper-class women within the salons. Enlightenment women, as is typical within traditional intellectual and Enlightenment histories, are not perceived as actors in Radical Enlightenment, but are instead acted upon and informed by men. ${ }^{20}$ Ulrich Im Hof's The Enlightenment, published in 1994, has only a short chapter dedicated to women that effectively places women within the household under the control of men. ${ }^{21}$ Both Hof and Himmelfarb pay significantly more attention to women in the Enlightenment then Paul Hazard's European Thought in the Eighteenth Century: From Montsquieu to Lessing (pub. 1946), which makes not mention of women at all. Even more recent histories focused on female involvement in the Enlightenment have faced significant difficulty placing women in the public sphere without placing them under the controlling influences of their husbands or fathers.

This traditional appropriation of women into history, acted upon instead of acting, expands beyond the boundaries of intellectual history and into political and social history. Within Western ideology men have been associated with the political sphere and the concept of "the man of the people." ${ }^{22}$ Within the categorization of men as political beings comes the implicit exclusion of women from politics. This comes from the "positional superiority" of men within

\footnotetext{
${ }^{18}$ Ibid, 12-18.

${ }^{19}$ Gertrude Himmelfarb, The Roads to Modernity: the British, French, and American Enlightenments (New York: Random House, 2004), 109-112.

${ }^{20}$ Jonathan Israel, "Women, Philosophy, and Sexuality," in Radical Enlightenment: Philosophy and the Making of Modernity 1650-1750 (Oxford: Oxford University Press, 2001), 82-96. http://lib.myilibrary.com.login.ezproxy.library.ualberta.ca/Open.aspx?id=75871.

${ }^{21}$ Ulrich Im Hof, The Enlightenment, transl. William E. Yuill (Oxford: Blackwell, 1994), 247.

${ }^{22}$ Shannon Jackson, "Partial Publicity and Gendered Remembering: Figuring women in Culture and Performance," in Cultural Studies 17:5 (2003), 693. http://ehis.ebscohost.com.login.ezproxy.library.ualberta.ca/eds/pdfviewer/pdfviewer?sid=fd844e71-6a80-4237bd33-b69506949470\%40sessionmgr1 15\&vid=5\&hid=4.
} 
society based on male knowledge over the women. ${ }^{23}$ Within Susan P. Conner's history of women in politics, the female inability to understand the political sphere is clearly stated. Women who attempted to increase their political power through male friends and relatives earning the titles "influence peddlers, inveterate seductresses, or coquettes." ${ }^{24}$ More recent histories such as Anna Clark's "Women in Eighteenth-Century British Politics" recognize although "reformers tended to define citizenship in highly masculine terms" in many of these histories women still found their way into politics. ${ }^{25}$ However, the masculine terms continue to be used to define citizenship and political involvement in histories. Conner's article and others like it must be carefully analyzed to understand the male-oriented bias in history and to learn how to avoid passing it to the next generation of historians. The narrative of male dominance is problematic, because it represents an over-simplification of history where only select individuals were active and those who were not members of the select could not succeed in becoming active. The narrative naturalizes the hierarchy within intellectual history and political history that places upper-class women at the bottom and excludes lower-class women entirely.

Olwen Hufton and Hesse have suggested lower-class women were involved within both political and intellectual life. Historians such as Felicia Gordon, who examined the figures of Marie Madeleine Jodin and Mary Darby Robinson, study women in middle class circles who gained some political influence. ${ }^{26}$ Lower-class women gained significant power during the prerevolutionary Enlightenment in France, exemplified by the Fishwives March to Versailles and the adoption of the lower class dialect by upper-class members of society. ${ }^{27}$ In The Other Enlightenment Hesse examines the dialect of the upper and lower social groups, fishwives and the salonnaires and how the two dialects became connected. Similarly, Goodman explored the written work of salonnaires and the limitations placed on them by education. This work has identified a significant gender gap in the social and intellectual abilities of female salonnaires and male intellectuals. ${ }^{28}$

The gap identified by Goodman was caused by an identifiable difference in the education provided to men and women. Robespierre and de la Barre advocated improving women's education to cultivate women's natural reason and intelligence. De la Barre advocated providing women with an education so they could overcome their mental inertia, ${ }^{29}$ while Robespierre believed education would cultivate a woman's natural intellect. ${ }^{30}$ Goodman in " L'ortografe des dames: Gender and Language in the Old Regime" fails to provide rational for the difference in

\footnotetext{
${ }^{23}$ Said, 7.

${ }^{24}$ Susan P. Conner, "Women and Politics," in French Women and the Age of Enlightenment, ed. Samia I Spencer (Bloomington: Indiana University Press, 1984), 52.

${ }_{25}$ Anna Clark, "Women in Eighteenth-Century British Politics,"in Women, Gender, and Enlightenment, ed. Sarah Knott and Barbara Taylor (London: Palgrave Macmillan, 2005), 570.

${ }^{26}$ Felica Gordon, "Filles publiques or Public Women: The Actress as Citizen: Marie Madeleine Jodin (1741-90) and Mary Darby Robinson (1758-1800)," in Women, Gender, and Enlightenment, ed. Sarah Knott and Barbara Taylor (London: Palgrave Macmillan, 2005), 610-629.

${ }^{27}$ Hesse, The Other Enlightenment, 10-25. Olwen H. Hufton, Women and the Limits of Citizenship in the French Revolution (Toronto: University of Toronto Press, 1992), 15.

${ }^{28}$ Dena Goodman, "L'ortografe des dames: Gender and Language in the Old Regime," in Women, Gender, and Enlightenment, ed. Sarah Knott and Barbara Taylor (London: Palgrave Macmillan, 2005), 195-223.

${ }^{29}$ Poullain de la Barre, "On the Education of Ladies," in Three Cartesian Feminist Treatises, introduction and annotations by Marcelle Maistre Welch, transl. Vivien Bosley (Chicago: University of Chicago Press, 2002), 139251. http://site.ebrary.com.login.ezproxy.library.ualberta.ca/lib/ualberta/docDetail.action?docID=10209999.

${ }^{30}$ Sepinwall, 8.
} 
education. She does provide an excellent record of the differences in education in regards to writing and speech.

Education offered women the opportunity to produce written work, which, because of the advent of the printing press, gave way to a barrage of female publications. Karen O'Brien identifies a number of female writers in Britain during the eighteenth century and a newly emerging collective self-consciousness among female authors. O'Brien views Maria Edgeworth's Helen as indicative of the increasing consciousness of women. Women, based on their shifting consciousness, were changing how they represented themselves within literature. ${ }^{31}$ Hesse identified women as using literature as a way to "engage in public discourse without overexposing their person to male scrutiny." 32 Hesse has done significant work in examining how women represented themselves within fiction to avoid male scrutiny, while constructing themselves as active within the public sphere. ${ }^{33}$

Eva Tavor Bannet identifies two types of women who wrote during the Enlightenment period in Britain: matriarchs, who promoted female superiority, such as Mary Astell and Lady Masham; and egalitarians who believed there was no difference between men and women, such as Mary Wollstonecraft and Mary Hays. ${ }^{34}$ These sources illustrate yet another shortcoming within Habermas' theory of the separate private and public space. These portrayals of women were a movement away from the representation of women in novels such as Pamela, New Hélene, Clarissa and Emile, which portrayed women as obedient to men. These women represented the role women were expected to fulfil as wives and daughters. ${ }^{35}$ Increasingly the portrayal of female characters in novels written by women illustrated the increasing self-consciousness described by Edgeworth. The difference in the way male and female writers represented women is indicative of the breakdown of the binary of public and private sphere as explained below.

Habermas' spheres, particularly the social and the familial sphere, become increasingly polarized as the social sphere slowly becomes integrated with the public sphere. ${ }^{36}$ Habermas defines three separate spheres: the social sphere, what others expected of the members of their social class, the familial or interment sphere and the public sphere. These spheres, contrary to Habermas' theory of polarization, are inseparably intertwined. The portrayal of women within literature and how men expected women to act was reflected within male literature. How women felt they should be treated within the public sphere was reflected within their writing as well. Men, as has been illustrated above, published books in the public sphere describing how women and men should behave in both the familial and social sphere. The familial sphere and the social sphere were intertwined, because the social roles individuals were expected to fill were dictated by their roles within the familial sphere, for example women were mothers and wives and men were husbands, fathers and brothers. ${ }^{37}$ Publication of books, pamphlets and newspapers connected the private sphere with the public sphere. Publication proves a fallacy within the theory of Habermas' public

\footnotetext{
${ }^{31}$ Karen O'Brien, Women and Enlightenment in Eighteenth-Century Britain (Cambridge: Cambridge University Press, 2009), 2. http://ebooks.cambridge.org.login.ezproxy.library.ualberta.ca/ebook.jsf?bid=CBO9780511576317.

${ }_{33}^{32}$ Hesse, The Other Enlightenment, 138.

${ }^{33}$ Ibid, $130-153$.

${ }^{34}$ Eve Tavor Bannet, The Domestic Revolution: Enlightenment Feminisms and the Novel (Baltimore: Johns Hopkins University Press, 2000), 3-10.

${ }^{35}$ Hunt, The Family Romance, 58-60.

${ }^{36}$ Habermas, The Structural Transformation of the Public Sphere, 151-152.

${ }^{37}$ Lynn Hunt, The Family Romance of the French Revolution (Berkeley: University of California Press, 1992).
} 
sphere, because these public publications concern the private sphere. The spheres defined by Habermas are not polarized, but instead they all occur in relation to each other. Still the fear of women entering the public sphere, where they were already present, persisted particularly within politics.

The political history of the Enlightenment is still a men's game associated with monarchies, absolutism and male revolutionaries. Documents and records from the Enlightenment period portray women such as Marie-Antoinette and Olympe de Gouges, as women who attempted to transgress their "natural place" and became unnatural women. Records from the French Revolution about women in the public sphere illustrate the distrust of these women and the urgency in removing them from the public sphere by portraying them as social and sexual deviants within literature. ${ }^{38}$ Documents from the French Enlightenment, especially during the French Revolution, illustrate a particularly xenophobic attitude towards women in the public sphere. Within histories written prior to the 1990s, such as Conner's history, the active unnatural woman remains visible. In Conner's history women such as Madame de Tencin, who spend their lives attempting to increase their power, are ultimately portrayed as outcasts and monstrous. ${ }^{39}$ Women who reject their role as passive and attempt to gain more power, as in Conner's article, are inherently doomed to fail within the narrative of women within Western history.

Conner's article is representative of the passive-female and unnatural woman dichotomy. This form of history naturalizes the myth women are inferior and unable to hold the same power the superior male does. The myth of female inferiority and incompetence, proliferated by Rousseau and other Enlightenment thinkers, has contributed to the male hegemony within Enlightenment histories. The male within this historiography is the dominant force and representative of the great discoveries and progress of the Enlightenment. Women became the outliers and because they were not men and were therefore other, must have been resistant to political and social progress. Inclusion in the political and social sphere could have only proven destructive and their exclusion from these activities was justified. Women within this narrative are passive, because men- the "us"- were active and within this binary females- the "them"- can only be passive. ${ }^{40}$ Only within the past twenty years have feminist, cultural and social historians began to replace this myth with a historiography more focused on active mainstream and marginalized groups.

More recent articles and books reject the tradition of passive-women, active-men and acknowledge the role of both men and women within politics. A purely feminist reading of history runs the risk of giving women too much power or inserting women into a role they did not fill. Comparatively, Arianne Chernock in her article "Extending the 'Right of Election': Men's Arguments for Women's Political Representation in Late Enlightenment Britain" acknowledges the role of female activists, such as Wollstonecraft, while also recognizing men

\footnotetext{
${ }^{38}$ Pierre-Gaspard Chaumette, “Chaumette, Speech at City Hall Denouncing Women's Political Activism (17 November 1793)," in The French Revolution and Human Rights: A Brief Documentary History, translated, edited, and with an introduction by Lynn Hunt (New York: Bedford, 1996), 138-139. http://chnm.gmu.edu/. Unknown, "The Trial of Olympe de Gouges," in Women in Revolutionary Paris, 1789-1795, transl. Darline Gay Levy, Harriet Branson Applewhite, and Mary Durham Johnson (Illinois: University of Illinois Press, 1979), 254-259. http://chnm.gmu.edu/. Unknown, L'Autrichienne en Goguettes ou l'Orgie Royale; Opera Proverbe (1789), http://chnm.gmu.edu/. Unknown, Déscription de la Menagerie Royale d'Animaux Vivants (1789), http://chnm.gmu.edu/.

${ }^{39}$ Conner, "Women and Politics," 56.

${ }^{40}$ Said, Orientalism, 6-7.
} 
played a vital role in the push for female rights. ${ }^{41}$ However, Chernock borders on giving men too much authority and women not enough in her argument.

The shift away from elitist history and focusing purely on elite women such as Catherine the Great, Gabrielle Émilie du Châtelet, and other noble and upper-class women indicates another important shift within the historiography. ${ }^{42}$ In his study of academic prize competitions in France, Jeremy Caradonna revealed women competed with notable success in prize competitions in many different subjects. ${ }^{43}$ According to Caradonna forty-nine out of over two thousand prize competitions, a total of about $2.1 \%$, were either won or placed in by women. Several of these competitions were won even after the competitor made reference to her sex illustrating an unusual equality within Enlightenment society. ${ }^{44}$ Caradonna is not alone in his examination of women within prize competitions. John Iverson and Marie-Pascale Pieretti have also examined academic prize competitions. ${ }^{45}$ Within the scope of female authors in Enlightenment England, Paula R. Backscheider has examined the domination of women in the field of English prose fiction. ${ }^{46}$ Carla Hesse compliments the research done by Caradonna through a statistical analysis of female authors. Hesse explores the number of female authors who wrote novels, poetry and serious public topics, such as politics. ${ }^{47}$

The advantage to the approach employed by both Hesse and Caradonna in their examination of female participation within the literary sphere is both examine the full scope of the literary sphere. In comparison Backscheider only examines the scope of women's writing within fiction. Neither Caradonna nor Hesse assume women came to dominate the French literary sphere. Instead they examine the publications of women within the broader context of a male-dominated society. Habermas' theory of the public sphere is problematized by such histories. Felicia Gordon stated Habermas failed to take into account the connotations of being a public woman within his theory. To be a public woman, in the sense of the Habermas' capitalist public sphere, implies a connection to the market. The public woman existed before what Habermas identifies as the creation of the public sphere as a prostitute. ${ }^{48}$ This connotation shunned and abused women in the public sphere and attacked their morality and virtue. However, Caradonna illustrated male intellectuals were not always hostile to their female counterparts. In fact, those women who won academic competitions received significant support and praise from the male

\footnotetext{
${ }^{41}$ Arianne Chernock, “Extending the 'Right of Election': Men's Arguments for Women's Political Representation in Late Enlightenment Britain," in Women, Gender, and Enlightenment, ed. Sarah Knott and Barbara Taylor (London: Palgrave Macmillan, 2005), 587-609.

42 There are literally hundreds of biographies written on upper-class women such as Catherine the Great, Mary Wollstonecraft and influencial salonnaires such as Suzanne Necker and Marie Thérese Rodet Geoffrin. A few examples are: Robert K. Massie, Catherine the Great: Portrait of a Woman (New York: Random House, 2001).; Susan Laird, Mary Wollstonecraft: Philosophical Mother of Coeducation (London: Continuum International Pub. Group, 2008); etc.

${ }^{43}$ Jeremy L. Caradonna, The Enlightenment in Practice: Academic Prize Contests and Intellectual Culture in France 1670-1794 (Ithaca: Cornell University Press, 2012), 229-231.

44 ibid 107.

45 Sepinwall, 4.

${ }^{46}$ Paula R. Backscheider, “The Novel's Gendered Space,” in Revising Women: Eighteenth-Century “Women's Fiction" and Social Engagement, ed. Paula R. Backscheider (Baltimore: John Hopkins UP, 2000 ), 3.

${ }^{47}$ Hesse, The Other Enlightenment, 53. Caradonna, 229-231.

${ }^{48}$ Felicia Gordon, 610-611.
} 
community. Some women even gained entry into French Academies through their entries in competitions. $^{49}$

Many traditional histories of the Enlightenment fail to discuss female involvement in the public sphere. However, intellectual institutions, including the publishing industry, cannot be isolated from the private sphere. Hesse has done significant work examining how female authors used fiction and other "acceptable forms of female writing" to provide commentary on public discourse. The medium of novel or poetry proved to be safer, particularly during the postThermidorian years of France, then direct political commentary, which for women such as Olympe de Gouges proved to be disastrous. ${ }^{50}$ Still women played an important role within intellectual, social, political and cultural Enlightenment history and their involvement cannot be underestimated and left unrepresented.

Only within the last twenty years has the role women played within history become the focus of historians. The historiography of women in the Enlightenment is still in the first stages of development. Women have been left out of the classical historiography of the Enlightenment, because, as illustrated above, traditional intellectual histories such as those written by Hazard and Himmelfarb excluded women completely or marginalized them as inactive without men. However, historians such as Dena Goodman, in their work to bring women back into history, have overestimated the role women played within history.

The focus of most intellectual history, the dominant field of Enlightenment history, is powerful and influential men such as Voltaire and Rousseau. Histories have focused primarily on philosophers who've created important theories and other men of influence such as patrons and kings. Unfortunately, recent work in women's history is not exempt from focusing on the "great women" of history or even women associated with the great men of history. Women such as Voltaire's mistress Madame de Châtelet have had numerous biographies published because of her famous relationship with Voltaire. Even her status as a great woman has not kept her from marginalization. Although Madame du Châtelet was a translator, mathematician, leading authority on Newton and essayist, via academic prize competitions, she is immortalized because of her relationship with Voltaire. A recent popular biography of Madame de Châtelet illustrates the steps taken towards recognizing her individual achievements. Still, even this biography places enormous emphasis on her relationship with Voltaire and continues to contribute her work to the male figures in her life. ${ }^{51}$ Thus even "great women" known for their achievements within history cannot escape the shadows of the great men who tower over them.

Essentially women within traditional Western history have represented the "Other" great men are measured against. Edward Said in his book Orientalism stated, "the relationship between Occident and Orient is a relationship of power, of domination, of varying degrees of a complex hegemony." ${ }^{2}$ The relationship between the historical male intellectual and women can be explained along these same terms. Even within women's history all statistics and all methods of recording history illustrate female intellectuals were not as common as male intellectuals in the Enlightenment. Within Hesse's study of French women during the Enlightenment the number of

\footnotetext{
${ }^{49}$ Caradonna, The Enlightenment in Practice, 110-111

${ }^{50}$ Hesse, The Other Enlightenment, 136-142.

51 Judith P. Zinsser, Emilie Du Chatelet: Daring Genius of the Enlightenment (New York: Penguin Books, 2007)

52 Said, Orientalism, 5.
} 
women publishing on certain topics. ${ }^{53}$ Still the vast number of women who played important roles within the Enlightenment have been forgotten or ignored. Future historiography must work to further bring women and other marginalized groups out of the shadows of Enlightenment philosophers and leaders to be analyzed and studied. Historians cannot isolate women from men, because the two groups are intertwined. However, they cannot ignore the role women played within Enlightenment society either or they risk continuing the hegemony within the historiography. There is still a lot of work to be done by historians within the Enlightenment breaking down the great men histories and Habermas' problematic public-private sphere binary. Still it is evident that throughout the last two decades there has been significant movement away from the male-centric history of the Enlightenment.

\section{Bibliography}

Backscheider, Paula R. “The Novel's Gendered Space.” Revising Women: Eighteenth-Century “Women's Fiction” and Social Engagement. ed. Paula R. Backscheider. 1-30.Baltimore: John Hopkins UP, 2000. Print.

Bannet, Eve Tavor. The Domestic Revolution: Enlightenment Feminisms and the Novel. Baltimore: Johns Hopkins University Press, 2000.

Barre, Poullain de la. "On the Education of Ladies." Three Cartesian Feminist Treatises. introduction and annotations by Marcelle Maistre Welch, transl. Vivien Bosley. 139-251. Chicago: University of Chicago Press, 2002.

http://site.ebrary.com.login.ezproxy.library.ualberta.ca/lib/ualberta/docDetail.action?docI $\mathrm{D}=10209999$. Ebook.

Caradonna, Jeremy L. The Enlightenment in Practice: Academic Prize Contests and Intellectual Culture in France 1670-1794. Ithaca: Cornell University Press, 2012. Print.

Chaumette, Pierre-Gaspard. “Chaumette, Speech at City Hall Denouncing Women's Political Activism (17 November 1793)." The French Revolution and Human Rights: A Brief Documentary History. Translated, edited, and with an introduction by Lynn Hunt. 138139. New York: Bedford, 1996. http://chnm.gmu.edu/.

Chernock, Arianne “Extending the 'Right of Election': Men's Arguments for Women's Political Representation in Late Enlightenment Britain." Women, Gender, and Enlightenment. ed. Sarah Knott and Barbara Taylor. 587-609. London: Palgrave Macmillan, 2005. Print.

Clark, Anna. "Women in Eighteenth-Century British Politics." Women, Gender, and Enlightenment. ed. Sarah Knott and Barbara Taylor. 570-586. London: Palgrave Macmillan, 2005. Print.

Conner, Susan P. "Women and Politics," French Women and the Age of Enlightenment. ed. Samia I Spencer. Bloomington: Indiana University Press, 1984. Print.

\footnotetext{
${ }^{53}$ Hesse, The Other Enlightenment, 53.
} 
Goodman, Dena. "L'ortografe des dames: Gender and Language in the Old Regime." Women, Gender, and Enlightenment. ed. Sarah Knott and Barbara Taylor. 195-223. London: Palgrave Macmillan, 2005. Print.

---------. The Republic of Letters: A Cultural History of the French Enlightenment. New York: Cornell University, 1994. Print.

Gordon,Felica. "Filles publiques or Public Women: The Actress as Citizen: Marie Madeleine Jodin (1741-90) and Mary Darby Robinson (1758-1800)." Women, Gender, and Enlightenment. ed. Sarah Knott and Barbara Taylor. 610-629. London: Palgrave Macmillan, 2005. Print.

Habermas, Jürgen. The Structural Transformation of the Public Sphere: An Inquiry into a Category of the Bourgeois Society. translated by Thomas Burger assisted by Frederick Lawrence. Cambridge: MIT Press, 1991. Print.

Hesse, Carla. The Other Enlightenment: How French Women Became Modern. Princeton: Princeton University Press, 2003. Print.

Himmelfarb, Gertrude. The Roads to Modernity: the British, French, and American Enlightenments. New York: Random House, 2004. Print.

Hof, Ulrich Im. The Enlightenment. transl. William E. Yuill. Oxford: Blackwell, 1994. Print.

Hufton, Olwen H. Women and the Limits of Citizenship in the French Revolution. Toronto: University of Toronto Press, 1992. Print.

Hunt, Lynn. Inventing Human Rights: A History. New York: W. W. Norton and Company, 2007. Print.

---------. The Family Romance of the French Revolution. Berkeley: University of California Press, 1992. Online.

Israel, Jonathan. "Women, Philosophy, and Sexuality." Radical Enlightenment: Philosophy and the Making of Modernity 1650-1750. Oxford: Oxford University Press, 2001. 82-96. http://lib.myilibrary.com.login.ezproxy.library.ualberta.ca/Open.aspx?id=75871. Ebook.

Jackson, Shannon. "Partial Publicity and Gendered Remembering: Figuring women in Culture and Performance." Cultural Studies 17:5 (2003). http://ehis.ebscohost.com.login.ezproxy.library.ualberta.ca/eds/pdfviewer/pdfviewer?sid= fd844e71-6a80-4237-bd33-b69506949470\%40sessionmgr115\&vid=5\&hid=4. Online.

Landes, Joan B. Women and the Public Sphere in the Age of the French Revolution. Ithaca, NY: Cornell University Press, 1988. Print. 
Laird, Susan. Mary Wollstonecraft: Philosophical Mother of Coeducation. London: Continuum International Pub. Group, 2008. Print.

Lilti, Antoine. "Sociability and Mondanité: Men of Letters in the Parisian Salons of the Eighteenth Century." transl. Jeremy Caradonna. n.d. 1-29. Print.

Mander, Jenny. "No Women is an Island: The Female Figure in French Enlightenment Anthropology." Women, Gender, and Enlightenment. ed. Sarah Knott and Barbara Taylor.97-116. New York: Palgrave Macmillan. Print.

Massie, Robert K. Catherine the Great: Portrait of a Woman. New York: Random House, 2001. Print.

O'Brien, Karen. Women and Enlightenment in Eighteenth-Century Britain. Cambridge: Cambridge University Press, 2009. http://ebooks.cambridge.org.login.ezproxy.library.ualberta.ca/ebook.jsf?bid=CBO978051 1576317. Ebook.

Rousseau, Jean-Jacques. "Emile (1762)." in Women, the Family, and Freedom: The Debate in Documents, vol 1: 1750-1889. ed by Susan Groag Bell and Karen M. Offen. Stanford: Stanford University Press, 1983. 43-49. http://chnm.gmu.edu/revolution/searchfr.php?function $=$ find $\& x=0 \& y=0 \&$ keyword $=$ Emile \#. Online.

Scott, Joan Wallach. Only Paradoxes to Offer: French Feminists and the Rights of Man. Cambridge: Harvard University Press, 1996. Print.

Sepinwall, Alyssa Goldstein. "Robespierre, Old Regime Feminist? Gender, the Late Eighteenth Century, and the French Revolution Revisited." The Journal of Modern History 82:1 (March 2010). 1-29. http://ehis.ebscohost.com.login.ezproxy.library.ualberta.ca/eds/pdfviewer/pdfviewer?sid= fd844e71-6a80-4237-bd33-b69506949470\%40sessionmgr115\&vid=4\&hid=117. Online.

Unknown. Déscription de la Menagerie Royale d'Animaux Vivants (1789).

http://chnm.gmu.edu/. Online.

Unknown. L'Autrichienne en Goguettes ou l'Orgie Royale; Opera Proverbe (1789). http://chnm.gmu.edu/. Online.

Unknown. "The Trial of Olympe de Gouges." Women in Revolutionary Paris, 1789-1795. transl. Darline Gay Levy, Harriet Branson Applewhite, and Mary Durham Johnson. 254-259. Illinois: University of Illinois Press, 1979. http://chnm.gmu.edu/. Online

Zinsser, Judith P. Emilie Du Chatelet: Daring Genius of the Enlightenment. New York: Penguin Books, 2007. Print. 